\title{
A Comparative Study on the Integration of Exogenous DNA into Mouse, Rat, Rabbit, and Pig Genomes
}

\author{
Masumi HIRABAYASHI), Ri-ichi TAKAHASHI1), Kazumi ITO1), \\ Naomi KASHIWAZAKI 1)*, Masao HIRAO2), Kazuo HIRASAWA2), \\ Shinichi $\mathrm{HOCHI}^{3)}$, and Masatsugu UEDA ${ }^{1)}$
}

\begin{abstract}
1)YS New Technology Inst., Inc., 519 Shimoishibashi, Ishibashi-machi, Shimotsuga-gun, Tochigi 329-0512, 2)Ina Research Laboratory, Kitayama Labes Co. Ltd., 3052-1 Ina, Ina-shi, Nagano 396-0021, 3) Faculty of Textile Science and Technology, Shinshu University, 3-15-1 Tokida, Ueda-shi, Nagano 386-8567, and *Present address: School of Veterinary Medicine, Azabu University, Sagamihara-shi, Kanagawa 229-8501, Japan
\end{abstract}

\begin{abstract}
Transgenic mammals, from small laboratory rodents to domestic animals, have been successfully produced to date, but their production efficiency within or across species has been variable. This is probably due to the differences in the type of injected DNA and/ or technical procedures employed in each laboratory, as well as the reproductive characteristics of the species. Here we report the direct comparison of the efficiencies of producing transgenic mice, rats, rabbits and pigs by one technician using a fusion gene composed of the bovine $\alpha S_{1}$-casein promoter and human growth hormone ( $\left.h G H\right)$ gene. Before the fusion gene was injected into the zygotes, high magnitude centrifugation to visualize the pronuclei was necessary for all of the pig zygotes and one-third of the rabbit zygotes, but not for mouse and rat zygotes. Post-injection survival of the mouse zygotes (67.1\%) was lower than those of the rat, rabbit and pig zygotes (89.6 to 100\%). The volume change of the pronucleus following DNA injection was the lowest in mice (50\% increase), moderate in rabbits (148\% increase), and the most prominent in rats (238\% increase). The data from only 1 pig zygote indicated a $22 \%$ increase in the pronucleus volume by DNA injection. The PCR analyses of the tail DNA of new born offspring indicated that $0.8 \%$ (4/ 493), $4.8 \%$ (22/463), $0.8 \%$ (3/367) and 0.9\% (2/221) of the injected eggs in mice, rats, rabbits and pigs, respectively, developed into transgenic offspring. Some of the founder animals in all four species expressed the transgene in the mammary gland which was confirmed in hGH mRNA by RT-PCR and/or hGH peptide in Witch's milk with ELISA. These results suggest that the maximum volume of DNA solution injectable into the pronucleus is a possible factor explaining the species differences in the production of transgenic animals.
\end{abstract}

Key words: centrifugation, DNA microinjection, $h G H$, milk proteins, transgenesis 


\section{Introduction}

Following the first report of transgenic mice [7], the integration of exogenous DNA into the genomes of other mammalian species, including rats, rabbits, goats, sheep, pigs and cattle, has been successfully achieved $[26,37]$. The efficiency in producing transgenic animals within and across species has been quite variable. In the production of transgenic mice it was reported that 0.5 to $10.0 \%$ of the DNA-microinjected zygotes developed into offspring carrying exogenous DNA [2, $3,19,22,34]$. A range of 0.4 to $4.8 \%$ of the DNAmicroinjected rat zygotes were reported to develop into transgenic rats $[4,13,15,17,20,32]$, and in rabbits and pigs, 0.3 to $2.6 \%[1,18,21,30,31]$ and 0.3 to $1.4 \%[8,27-29,36]$ of the DNA-microinjected zygotes developed into the transgenic animals, respectively. However, concluding that the efficiency of producing transgenic animals is dependent on the body size of the animals based on these reports is problematic, because a great variety of exogenous DNA constructs and technical protocols for DNA microinjection were employed in each laboratory. The reproductive potential of the individual animal species (e.g., number of offspring viable after embryo transfer) also needs to be considered for the differences in the efficiency of producing transgenic animals.

In the present study, a single gene construct was microinjected by one skillful technician into pronuclear zygotes from mice, rats, rabbits and pigs, and the efficiencies of producing the transgenic animals were compared among the four species. In addition, the expression of the transgenes in the mammary glands was examined both in mRNA by RT-PCR and in peptide by ELISA.

\section{Materials and Methods}

Preparation of exogenous DNA: A fusion gene construct of bovine $\alpha \mathrm{S}_{1}$-casein and human growth hormone (hGH) was prepared according to previously reported methods [23]. Briefly, the HindIII/BamHI fragments of the 5' regulatory region of the bovine $\alpha \mathrm{S}_{1}$-casein gene were prepared by PCR, and inserted into the BamHI sites of the plasmid p0GH containing the coding regions, introns, and poly-A signal of hGH (Nicholas Institute Diagnostics, CA, USA). The re- combinant plasmids were digested with HindIII and $\mathrm{Xba \textrm {I }}$. The fusion genes were separated by $1.2 \%$ agarose gel electrophoresis and extracted from the gel with Geneclean II (BIO101, CA, USA). For microinjection, the DNA $(2.8 \mathrm{~kb})$ was dissolved in $10 \mathrm{mM}$ Tris- $\mathrm{HCl}$ (pH 7.6)/0.1 mM EDTA to yield a final concentration of $5 \mu \mathrm{g} / \mathrm{m} l$ and stored at $-20^{\circ} \mathrm{C}$ until use.

Pronuclear microinjection in the mice: Specificpathogen-free (SPF)/virus antibody-free (VAF) Crj:B6D2F1 (Charles River Japan, Yokohama, Japan) female mice ( 8 to 13 weeks old) were superovulated by intraperitoneal (i.p.) injections of 5 IU equine chorionic gonadotropin (eCG: Nippon Zenyaku, Fukushima, Japan), and 5 IU human chorionic gonadotropin (hCG: Sankyo, Tokyo, Japan) after a 48-hr interval, and coupled overnight with C57BL/6NCrj male mice. The pronuclear-stage zygotes were collected $20 \mathrm{hr}$ after the hCG injection and placed in Dulbecco's phosphate buffered saline (D-PBS; Nissui Pharmaceuticals, Tokyo, Japan) supplemented with $20 \%$ fetal bovine serum (FBS; Equitech Bio, TX, USA). The maximum volume of exogenous DNA solution was microinjected into the male pronucleus with the aid of a pair of manipulators (MO-102 and MO-103; Narishige Scientific Instrument Laboratory, Tokyo, Japan) at $\times 200$ magnification (Fig. 1-A) as previously reported [16]. One to $2 \mathrm{hr}$ later, the morphologically surviving DNA-injected zygotes in Whitten's medium [40] were transferred to the oviducts of pseudopregnant ICR mice (19 to 29 zygotes per recipient). The pseudopregnancy of the females was induced by mating with vasectomized males.

Pronuclear microinjection in the rats: SPF/VAF Crj:Wistar female rats (10 to 15 weeks old) were superovulated by i.p. injections of $20 \mathrm{IU}$ eCG and $10 \mathrm{IU}$ hCG, and coupled with male rats of the same strain. The pronuclear zygotes were collected $17 \mathrm{hr}$ after the hCG injection. The introduction of the pipet tip into the male pronucleus was facilitated by finger touching of the microscope stage (micro-vibration) as recently reported [33], and then the maximum volume of DNA solution was microinjected (Fig. 1-B). The surviving zygotes in modified Krebs-Ringer bicarbonate solution [35] were transferred to the oviducts of pseudopregnant Wistar rats (21 to 30 zygotes per recipient).

Pronuclear microinjection in the rabbits: Kbs:JW female rabbits ( 3.5 to $4.5 \mathrm{~kg}$ weight) were superovulated 

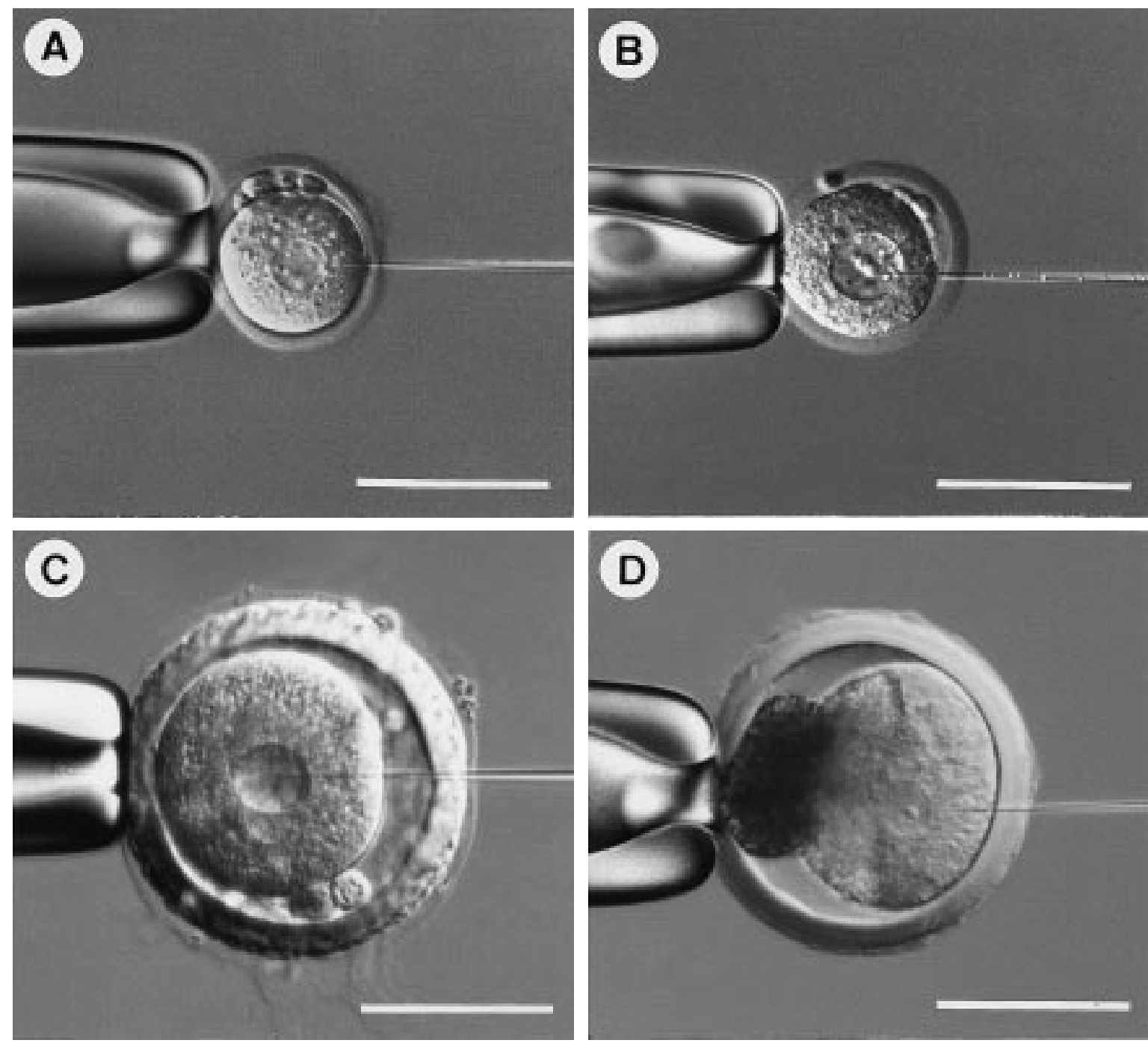

Fig. 1. DNA-microinjected pronuclear zygotes from mouse (A), rat (B), rabbit (C) and pig (D). Bar=100- $\mu \mathrm{m}$.

by a single subcutaneous (s.c.) injection of $3.0 \mathrm{AU}$ porcine follicle stimulating hormone (Denka Pharmaceuticals, Japan) dissolved in $10 \%$ polyvinylpyrrolidone (Wako Pure Chemical Industries, Japan) as previously described [10], followed by a s.c. injection of $75 \mathrm{IU}$ hCG $72 \mathrm{hr}$ later. The females were mated with male rabbits of the same strain, and 17 to $19 \mathrm{hr}$ after the hCG injection, pronuclear zygotes were collected by oviduct flushing. When the pronuclei of the zygotes were not detected during microscopic observation at $\times 200$ magnification, the zygotes were centrifuged for $10 \mathrm{~min}$ at $12,000 \times \mathrm{g}$ to visualize their pronuclei. DNA microinjection until maximum expansion of the male pronucleus was then performed (Fig.
1-C).

The surviving zygotes in TCM199 supplemented with $10 \%$ FBS were transferred to the oviduct ampullae of Kbs:JW recipient rabbits that had received 75 IU hCG at the same time as the embryo donors (20 to $40 \mathrm{zy}$ gotes per recipient).

Pronuclear microinjection in pigs: The Landrace $\times$ Large White hybrid gilts (6 to 7 months old, 100 to 110 $\mathrm{kg}$ weight) were superovulated by intramuscular injections of 1,000 IU eCG and $500 \mathrm{IU}$ hCG $72 \mathrm{hr}$ apart, and coupled with Durock boars. Pronuclear zygotes were collected 50 to $56 \mathrm{hr}$ after the hCG injection, and centrifuged for $10 \mathrm{~min}$ at $12,000 \times \mathrm{g}$. The DNA solution was microinjected into either the male or female 
pronucleus until the maximum expansion (Fig. 1-D). The zygotes in Whitten's medium were transferred to the oviduct ampullae of recipient gilts that had received $500 \mathrm{IU}$ hCG on the preceding day (9 to 36 zygotes per recipient).

Pronuclear volume changes: The pronuclear volumes were calculated from microphotographs of the visible pronucleus taken before and after DNA microinjection. The injected DNA volume (\% increase) was expressed as the ratio relative to the pronuclear volume before DNA microinjection.

Identification and expression of transgenes: The presence or absence of the transgenes in the resultant newborn animals was examined as previously reported [23]. The expression of hGH genes in neonatal mammary glands was examined in mRNA by RT-PCR and in peptide by ELISA, as previously reported [12].

Statistical analysis: Pronuclear expansion by DNA microinjection in the four species was compared by one-way ANOVA. The percentage data in each replicate for transgenic production (post-injection survival, in vivo development, transgenic pups ratio, and overall efficiency producing transgenic animals) were arcsintransformed before being subjected to one-way ANOVA. The significant differences were determined by Scheffe's multiple comparison test using
STATVIEW (Abacus Concepts, CA, USA). A value of $\mathrm{P}<0.05$ was chosen as an indication of statistical significance.

\section{Results}

Pronuclear characteristics: Species difference in the pronuclear expansion following DNA microinjection was detected as shown in Table 1. The size of the pronucleus before DNA injection was similar between mice and rats, but the rat pronucleus after injection of the maximum volume of DNA solution expanded more than the mouse pronucleus ( 238 vs. $50 \%$ increase in volume). The levels of maximum expansion in the rabbit pronucleus were the intermediate ( $148 \%$ increase) of those in the mouse and rat pronuclei. The expansion data from only 1 pig zygote indicated a $22 \%$ increase in the pronucleus volume by DNA injection.

Efficiency producing transgenic animals: High magnitude centrifugation was necessary for all 221 pig zygotes and 132 (36.0\%) of the 367 rabbit zygotes, but not for the mouse and rat zygotes to visualize their pronuclei. As shown in Table 2, post-injection survival of the mouse zygotes $(67.1 \%)$ was significantly lower than those of the rat, rabbit and pig zygotes (89.6 to $100 \%$ ). Transfer of the surviving zygotes into re-

Table 1. Volume changes in mouse, rat, rabbit and pig pronucleus following DNA microinjection

\begin{tabular}{lcccc}
\hline \multirow{2}{*}{ Species } & \multirow{2}{*}{$\begin{array}{c}\text { No. of zygotes } \\
\text { assessed }\end{array}$} & \multicolumn{3}{c}{ Volume of pronucleus $(\mathrm{pL}):$ Mean \pm SE } \\
\cline { 3 - 5 } & 10 & Pre-injection & Post-injection & $(\%$ increase $)$ \\
\hline Mouse & 10 & $6.8 \pm 0.5$ & $9.7 \pm 0.4$ & $(50 \pm 13)^{\mathrm{a}}$ \\
Rat & 10 & $6.7 \pm 1.0$ & $16.2 \pm 2.9$ & $(148 \pm 41)^{\mathrm{a}}$ \\
Rabbit & 1 & 11.8 & 14.4 & $(22)^{\mathrm{a}}$ \\
Pig & &
\end{tabular}

a, b Different superscripts within a column denote significant differences.

Table 2. Production of transgenic mice, rats, rabbits, and pigs carrying hGH gene

\begin{tabular}{lccccc}
\hline Species & $\begin{array}{c}\text { No. of } \\
\text { replicates }\end{array}$ & $\begin{array}{c}\text { Post-injection } \\
\text { survival }\end{array}$ & $\begin{array}{c}\text { Development } \\
\text { in vivo }\end{array}$ & $\begin{array}{c}\text { Proportion of } \\
\text { transgenic pups }\end{array}$ & $\begin{array}{c}\text { Overall } \\
\text { efficiency }\end{array}$ \\
\hline Mouse & 5 & $67.1 \%(331 / 493)^{\mathrm{a}}$ & $40.8 \%(135 / 331)^{\mathrm{b}}$ & $3.0 \%(4 / 135)^{\mathrm{ab}}$ & $0.8 \%^{\mathrm{a}}$ \\
Rat & 4 & $89.6 \%(415 / 463)^{\mathrm{b}}$ & $36.4 \%(151 / 415)^{\mathrm{ab}}$ & $14.6 \%(22 / 151)^{\mathrm{b}}$ & $4.8 \%^{\mathrm{b}}$ \\
Rabbit & 4 & $95.6 \%(351 / 367)^{\mathrm{b}}$ & $12.3 \%(43 / 351)^{\mathrm{ab}}$ & $7.0 \%(3 / 43)^{\mathrm{a}}$ & $0.8 \%^{\mathrm{a}}$ \\
Pig & 8 & $100 \%(221 / 221)^{\mathrm{c}}$ & $18.6 \%(41 / 221)^{\mathrm{a}}$ & $4.9 \%\left(2^{\mathrm{a}} / 41\right)^{\mathrm{a}}$ & $0.9 \%^{\mathrm{a}}$ \\
\hline
\end{tabular}

a-c Different superscripts within columns denote significant differences. ${ }^{1}$ No. of transgenic offspring / No. of eggs injected. *One of them was stillborn. 
Table 3. Expression of hGH gene in mammary gland tissues of transgenic founders

\begin{tabular}{lcll}
\hline & \multicolumn{3}{c}{ No. $(\%)$ of transgenic founders expressed hGH } \\
\cline { 2 - 4 } Species & mRNA & \multicolumn{2}{c}{ Peptide } \\
\hline Mouse & $1 / 4 \quad(25.0)$ & $1 / 4 \quad(25.0)$ \\
Rat & $11 / 22(50.0)$ & $7 / 22(31.8)$ \\
Rabbit & $2 / 3 \quad(66.7)$ & $0 / 3 \quad(0)$ \\
Pig & $1 / 1 \quad(100)$ & $0 / 1 \quad(0)$ \\
\hline
\end{tabular}

cipient females resulted in a higher proportion of newborn offspring in the mice and rats (40.8 and 36.4\%, respectively) than in the rabbits and pigs (12.3 and $18.6 \%$, respectively). The mean proportion of transgenic rats among all the offspring born (14.6\%) was 2.1 to 4.9 times higher than those of the transgenic mice, rabbits and pigs (3.0 to $7.0 \%$ ). The overall efficiency of producing transgenic animals was the highest in rats ( $4.8 \%$ of injected zygotes), followed by the three other species (pigs, $0.9 \%$; rabbits, $0.8 \%$; mice, $0.8 \%$; $\mathrm{P}<0.05$ vs. rats).

Transgene expression: As shown in Table 3, the expression of the hGH transgenes in the mammary glands of some transgenic founders from all four species was confirmed at the mRNA level by RT-PCR, although only small sample numbers were available in mice, rabbits and pigs. The hGH peptide was detected by ELISA in 1 transgenic mouse and 7 transgenic rats. In the pigs, two daughters of the male transgenic founder were found to provide lactating milk which contained a mean hGH concentration of $0.13 \mathrm{mg} / \mathrm{mL}$ (data not shown).

\section{Discussion}

Pronuclear microinjection of a single gene construct by one technician resulted in the production of transgenic animals at the efficiencies of $4.8 \%$ in rats, $0.9 \%$ in pigs, $0.8 \%$ in rabbits, and $0.8 \%$ in mice. Insertion of the injection pipet-tip into the mouse, rabbit, or pig pronucleus was very easy, but a higher proportion of mouse zygotes were damaged during the process of DNA microinjection. The post-injection survival rate of mouse zygotes in the present study $(67.1 \%)$ was within the range of variations (55 to $81 \%$ ) reported in previous studies $[2,7,16,34]$ and our background results (55 to 89\%; data not shown). Differences in the mouse strains and the breeding batches should be con- sidered for the post-injection survival of the pronuclear zygotes. On the other hand, DNA microinjection into the rat pronucleus seemed to be difficult because the pronuclear membrane is so sticky [5] and the cytoplasmic membrane is more resistant to penetration than that of the mouse embryos [9]. The post-injection survival rates of the rat zygotes have been reported as ranging from 32 to $65 \%[4,15,17,22,29,32$,], but an improved method of micropipet introduction into the rat pronucleus [33] made it possible to inject the amounts of DNA solution without detrimental effects on the rat zygotes in the present study.

The DNA-injected zygotes were transferred into recipient females, and the resulting offspring was lower in the rabbits and pigs (12.3 to $18.6 \%)$ than in the mice and rats (36.4 to $40.8 \%$ ). A part of the rabbit zygotes and all of the pig zygotes were centrifuged before DNA microinjection in order to visualize their pronuclei. However, the high magnitude $g$ force on the pronuclear zygotes themselves was reported not to be detrimental to their subsequent developmental potential in rabbits [11], pigs [39] and cattle [38]. The reduction in the developmental potential of the DNA-injected zygotes is known in mice $[2,3,19,22,34]$, rats $[4,5,13,15$, $17,20,23,32]$, rabbits $[8,21,30,31,39]$ and pigs [8, $24,27,28,36]$ to be from one-third to one-half of nontreated zygotes. In the present study, the maximum number of zygotes transferred into each recipient was the same in the four examined species and most of the recipient animals (13 of 13, 100\% in mice; 15 of 15 , $100 \%$ in rats; $8 / 11,73 \%$ in rabbits; 7 of $9,78 \%$ in pigs) became pregnant by the surgical transfer of the DNAinjected zygotes. Our previous reports indicated that $69 \%$ of the intact 2-cell stage rat embryos developed into offspring in vivo [14], whereas only 31 to $41 \%$ of intact pronuclear stage rabbit zygotes did [10]. Therefore, the species difference in the offspring rates may be due to the extent of performance in embryo transfer technology.

The proportion of offspring carrying the exogenous DNA was high in rats $(14.6 \%)$ but was equally low in mice, rabbits and pigs (3.0 to $7.0 \%$ ). The species differences in these transgenic offspring is marked by the swelling of the pronucleus after DNA microinjection, $238 \%$ in rats, $148 \%$ in rabbits, $50 \%$ in mice and $22 \%$ in pig, which may explain the overall difference in the efficiency of the transgenic animal production. The 
fully expanded pronucleus shrunk to its initial volume $1 \mathrm{hr}$ after DNA microinjection (data not shown), but the relative volume of the injected DNA solution must be a good indicator of the possibility that the exogenous DNA can contact the genome DNA.

Hammer et al. [8] reported using a single DNA construct such that transgenic rabbits, sheep, and pigs were produced at efficiencies of 13,1 , and $10 \%$ per newborn offspring, respectively. Concentrations of the injected DNA, buffer compositions, cell cycle of the pronuclear zygotes, and chromosomal characteristics were considered for the species differences in transgenic animal production. The strains for the embryo donors [13, 34], as well as the concentrations of injected DNA [2, 13] and the buffer compositions [2], are among the possible factors influencing the efficiencies producing transgenic mice and rats. It remains unclear in rabbits and pigs whether the optimum strains or breeds are present or not, and it is a subject which requires further research.

In the present study, expression of the integrated hGH gene was confirmed either at the mRNA or peptide level in all four species. The comparison between the animal species and the number of hGH-expressing lines was not valid because the sample numbers were so small. The screening method of the hGH-expressing transgenic founders immediately after birth [12], employed here, is effective with respect to time and cost savings for animal maintenance, particularly in the large animal species. The possibility and level of exogenous DNA expression in the transgenic founders are known to be influenced by the copy numbers and chromosomal sites of the integrated DNA, as well as the designs of the DNA constructs [6, 23, 25].

In conclusion, the species differences in the production of the hGH-expressing transgenic animals among mice, rats, rabbits, and pigs can be explained by the differences in the maximum volume of DNA solution injected into the pronucleus as well as the post-injection survival of the zygotes and their subsequent in vivo developmental potential. The direct comparative results in the present study contain useful information for researchers who have experience with DNA microinjection in particular animal species and intend to extend their techniques to other species.

\section{Acknowledgments}

The authors thank Akiyo Sekimoto, Hiromi Okikura (YS New Technology Institute Inc.), Setsuko Kitahara, Mikako Kamei (Kitayama Labes Co.), Megumi Kato, and Hiroaki Hattori (Shinshu University) for their skillful assistance on recovering and transferring the experimental zygotes. This study was supported by a grant from the Bio-oriented Technology Research Advancement Institution (BRAIN), Japan.

\section{References}

1. Aigner, B., Besenfelder, U., Seregi, J., Frenyo, L.V., SahinToth, T., and Brem, G. 1996. Expression of the murine wild-type tyrosinase gene in transgenic rabbits. Transgenic Res. 5: 405-411.

2. Brinster, R.L., Chen, H.Y., Trumbauer, M.E., Yagle, M.K., and Palmiter, R.D. 1985. Factors affecting the efficiency of introducting foreign DNA into mice by microinjecting eggs. Proc. Natl. Acad. Sci. USA. 82: 4438-4442.

3. Bucchini, D., Madsen, O., Desbois, P., Pictet, R., and Jami, J. 1989. B islet cells of pancreas are the site of expression of the human insulin gene in transgenic mice. Exp. Cell Res. 180: 467-474.

4. Charreau, B., Tesson, L., Buscail, J., Soulillou, J-P., and Anegon, I. 1996. Analysis of human CD59 tissue expression directed by the CMV-IE-1 promoter in transgenic rats. Transgenic Res. 5: 443-450.

5. Charreau, B., Tesson, L., Soulillou, J-P., Pourcel, C., and Anegon, I. 1996. Transgenesis in rats: Technical aspects and models. Transgenic Res. 5: 223-234.

6. Fujiwara, Y., Miwa, M., Takahashi, R., Kodaira, K., Hirabayashi, M., Suzuki, T., and Ueda, M. 1999. Highlevel expressing YAC vector for transgenic animal bioreactors. Mol. Reprod. Dev. 52: 414-420.

7. Gordon, J.W., Scangos, G.A., Plotkin, D.J., Barbosa, J.A., and Ruddle, F.H. 1980. Genetic transformation of mouse embryos by microinjection of purified DNA. Proc. Natl. Acad. Sci. USA. 77: 7380-7384.

8. Hammer, R.E., Pursel, V.G., Rexroad, C.E. Jr., Wall, R.J., Bolt, D.J., Ebert, K.M., Palmiter, R.D., and Brinster, R.L. 1985. Production of transgenic rabbits, sheep and pigs by microinjection. Nature 315: 680-683.

9. Heideman, J. 1991. Transgenic rats: A discussion. Bio/ Technology 16: 325-332.

10. Hirabayashi, M., Hirao, M., Hochi, S., Kimura, K., Hirasawa, K., and Ueda, M. 2000. Effects of superovulatory protocols on the recovery and subsequent developmental potential of rabbit zygotes (in Japanese). J. Exp. Anim. Technol. 35: 23-28.

11. Hirabayashi, M., Hirao, M., Kimura, K., Hirasawa, K., Ueda, M., and Hochi, S. 2000. Production of transgenic rabbits using centrifuged pronuclear zygotes. J. Vet. Med. Sci. 62: 1047-1052. 
12. Hirabayashi, M., Kodaira, K., Takahashi, R., Sagara, J., Suzuki, T., and Ueda, M. 1996. Transgene expression in mammary glands of newborn rats. Mol. Reprod. Dev. 43: $145-149$.

13. Hirabayashi, M., Takahashi, R., Ito, K., Kodaira, K., Suzuki, T., and Ueda, M. 1997. Factors affecting the producing efficiency of transgenic rats (in Japanese). J. Reprod. Dev. 43: $15-18$.

14. Hirabayashi, M., Takahashi, R., Sekiguchi, J., and Ueda, M. 1997. Viability of transgenic rat embryos after freezing and thawing. Exp. Anim. 46: 111-115.

15. Hochi, S., Ninomiya, T., Honma, M., and Yuki, A. 1990. Successful production of transgenic rats. Anim. Biotechnology 1: 175-184.

16. Hochi, S., Ninomiya, T., Mizuno, A., Honma, M., and Yuki, A. 1990. Fate of exogenous DNA carried into mouse eggs by spermatozoa. Anim. Biotechnology 1: 21-31.

17. Hochi, S., Ninomiya, T., Waga-Honma, M., and Yuki, A. 1992. Secretion of bovine $\alpha$-lactalbumin into the milk of transgenic rats. Mol. Reprod. Dev. 33: 160-164.

18. Hoeg, J.M., Vaisman, B.L., Demosky, S.J. Jr., Meyn, S.M., Talley, G.D., Hoyt, R.F. Jr., Feldman, S., Bérard, A.M., Sakai, N., Wood, D., Brousseau, M.E., Marcovina, S., Brewer, H.B. Jr., and Santamarina-Fojo, S. 1996. Lecthin: Cholesterol acyltransferase overexpression generates hyperalpha-lipoproteinemia and a nonatherogenic lipoprotein pattern in transgenic rabbits. J. Biol. Chem. 271: 4396-4402.

19. Iwakura, Y., Asano, M., Nishimune, Y., and Kawade, Y. 1988. Male sterility of transgenic mice carrying exogenous mouse interferon- $\beta$ gene under the control of metallothionein enhancer-promoter. EMBO J. 7: 37573762 .

20. Kajiwara, N., Sugiyama, F., Goto, Y., Sugiyama, Y., Fukamizu, A., Uehara, S., Sugimura, K., Murakami, K., Hokao, R., Akahori, F., and Yagami, K. 1993. Production of transgenic rats using pregnant and pseudopregnant rats prepared at a breeding farm. Exp. Anim. 42: 463-466.

21. Limonta, J.M., Castro, F.O., Martínez, R., Puentes, P., Ramos, B., Aguilar, A., Lleonart, R.L., and de la Fuente, J. 1995. Transgenic rabbits as bioreactors for the production of human growth hormone. J. Biotechnology 40: 49-58.

22. Murphy, L.J., Molnar, P., Lu, X., and Huang, H. 1995. Expression of human insulin-like growth factor-binding protein-3 in transgenic mice. J. Mol. Endocrinol. 15: 293303.

23. Ninomiya, T., Hirabayashi, M., Sagara, J., and Yuki, A. 1994. Function of milk protein gene 5' flanking regions on human growth hormone gene. Mol. Reprod. Dev. 37: 276283.

24. Nottle, M.B., Nagashima, H., Verma, P.J., Du, Z.T., Grupen, C.G., Ashman, R.J., and MacIlfatrick, S. 1997. Developments in transgenic techniques in pigs. J. Reprod. Fertil. Suppl. 52: 237-244.

25. Palmiter, R.D. and Brinster, R.L. 1986. Germ-line transformation of mice. Ann. Rev. Genet. 20: 465-499.
26. Prieto, P.A., Kopchick, J.J., and Kelder, B. 1999. Transgenic animals and nutrition research. J. Nutr. Biochem. 10: 682695.

27. Pursel, V.G., Rexroad, C.E. Jr., Bolt, D.J., Miller, K.F., Wall, R.J., Hammer, R.E., Pinkert, C.A., Palmiter, R.D., and Brinster, R.L. 1987. Progress on gene transfer in farm animals. Vet. Immunol. Immunopathol. 17: 303-312.

28. Pursel, V.G., Pinkert, C.A., Miller, K.F., Bolt, D.J., Campbell, R.G., Palmiter, R.D., Brinster, R.L., and Hammer, R.E. 1989. Genetic engineering of livestock. Science 244: 1281-1288.

29. Pursel, V.G. and Rexroad, C.E. Jr. 1993. Recent progress in the transgenic modification of swine and sheep. Mol. Reprod. Dev. 36: 251-254.

30. Snyder, B.W., Vitale, J., Milos, P., Gosselin, J., Gillespie, F., Ebert, K., Hague, B.F., Kindt, T.J., and Wadsworth, S. 1995. Developmental and tissue-specific expression of human CD4 in transgenic rabbits. Mol. Reprod. Dev. 40: 419-428.

31. Spieker-Polet, H., Sethupathi, P., Yam, P-C., and Knight, K.L. 1995. Rabbit monoclonal antibodies: Generating a fusion partner to produce rabbit-rabbit hybridomas. Proc. Natl. Acad. Sci. USA. 92: 9348-9352.

32. Swanson, M.E., Hughes, T.E., St. Denny, I., France, D.S., Paterniti, J.R. Jr., Tapparelli, C., Gfeller, P., and Bürki, K. 1992. High level expression of human apolipoprotein A-I in transgenic rats raises total serum high density lipoprotein cholesterol and lowers rat apolipoprotein A-I. Transgenic Res. 1: 142-147.

33. Takahashi, R., Hirabayashi, M., and Ueda, M. 1999. Production of transgenic rats using cryopreserved pronuclear-stage zygotes. Transgenic Res. 8: 397-400.

34. Taketo, M., Schroeder, A.C., Mobraaten, L.E., Gunning, K.B., Hanten, G., Fox, R.R., Roderick, T.H., Stewart, C.L., Lilly, F., Hansen, C.T., and Overbeek, P.A. 1991. FVB/N: An inbred mouse strain preferable for transgenic analyses. Proc. Natl. Acad. Sci. USA. 88: 2065-2069.

35. Toyoda, Y. and Chang, M.C. 1974. Fertilization of rat eggs in vitro by epididymal spermatozoa and the development of eggs following transfer. J. Reprod. Fertil. 36: 9-22.

36. Vize, P.D., Michalska, A.E., Ashman, R., Lloyd, B., Stone, B.A., Quinn, P., Wells, J.R.E., and Seamark, R.F. 1988. Introduction of porcine growth hormone fusion gene into transgenic pigs promotes growth. J. Cell Sci. 90: 295-300.

37. Wall, R.J. 1996. Transgenic livestock: Progress and prospects for the future. Theriogenology 45: 57-68.

38. Wall, R.J. and Hawk, H.W. 1988. Development of centrifuged cow zygotes cultured in rabbit oviducts. $J$. Reprod. Fertil. 82: 673-680.

39. Wall, R.J., Pursel, V.G., Hammer, R.E., and Brinster, R.L. 1985. Development of porcine ova that were centrifuged to permit visualization of pronuclei and nuclei. Biol. Reprod. 32: 645-651.

40. Whitten, W.K. 1971. Nutrient requirements for the culture of preimplantation embryos in vitro. Adv. Biosci. 6: 129 141. 